Studia nad Autorytaryzmem i Totalitaryzmem 41, nr 4 Wrocław 2019

DOI: 10.19195/2300-7249.41.4.10

RAFAŁ KANIA

ORCID: 0000-0003-2900-6695

Szkoła Wyższa im. Pawła Włodkowica w Płocku

\title{
Między ideologią i praxis. Organizacja socjalistyczna w PRL w latach 1956-1981
}

\section{Wprowadzenie. \\ Uwarunkowania polityczne i ideologiczne w Polsce po 1956 roku}

Prawidłowością systemów totalitarnych i autorytarnych jest dążenie do omnipotencji państwa. Tendencja ta była cechą charakteryzującą rzeczywistość PRL, dotykającą także nauk praktycznych ${ }^{1}$. Powodem ich silnej ideologizacji, oprócz immanentnej skłonności istniejącego systemu władzy do rozszerzania obszarów kontroli nad jednostką ${ }^{2}$, była konieczność poszukiwania skutecznego przekaźnika transmitującego teoretyczne, czy wręcz utopijne, założenia marksizmu-leninizmu na grunt praktyczny. W świetle oficjalnego stanowiska władz oraz zgodnych z nim koncepcji formułowanych na gruncie części nurtów nauk praktycznych państwo socjalistyczne miało stać się szczególnego rodzaju ogromnym holdingiem. Jego elementy składowe miały sprawnie realizować wizję wytyczoną przez partię komunistyczną, a ściślej — przez jej kierownictwo, na drodze budownictwa socjalistycznego. Celem artykułu jest przedstawienie głównych założeń teoretycznej koncepcji „organizacji socjalistycznej” formułowanej na bazie marksizmu-leninizmu w latach 1956-19813․ Dla badaczy doktryn politycznych i prawnych zainteresowanych

1 A. Podgórecki, Charakterystyka nauk praktycznych, Warszawa 1962, s. 23 n.; T. Pszczołowski, Mała encyklopedia prakseologii i teorii organizacji, Wrocław 1978, s. 130-131, 248-249.

${ }^{2}$ A. Walicki, Marksizm i skok do królestwa wolności. Dzieje komunistycznej utopii, Warszawa 1996, s. 310, 463.

3 Przyjęta cezura czasowa, lata 1956-1981, została zastosowana z dwóch powodów. Po pierwsze, wśród badaczy przeważa pogląd, że dzieje Polski, na które przypadały rządy komunistyczne, a więc lata 1944-1989, można podzielić na kilka okresów: 1) lata 1944-1956, czyli tak zwany okres „stalinowski”, w którym prowadzono w Polsce brutalną sowietyzację, a za jego apogeum uznać należy uchwalenie 22 lipca 1952 roku Konstytucji PRL; 2) lata 1956-1981, czyli okres

Studia nad Autorytaryzmem i Totalitaryzmem 41, nr 4, 2019

(C) for this edition by CNS 
relacją między sferą filozofii politycznej a praxis przedmiotowa problematyka wydaje się szczególnie interesująca, ponieważ w stopniu znaczącym została ona nasycona treściami ideologicznymi. Przedmiotową problematykę należy usytuować na pograniczu obszaru zainteresowań historii doktryn polityczno-prawnych i historii myśli organizatorskiej, przy czym z racji przyjętego celu badawczego w artykule przyznano prymat perspektywie poznawczej właściwej pierwszej z nich ${ }^{4}$.

Wraz z zakończeniem okresu nazywanego „stalinizmem” i „odwilżą” roku 1956 rozpoczął się w historii PRL etap tak zwanego realnego socjalizmu ${ }^{5}$. Podjęto wtedy próbę łagodzenia quasi-totalitarnego systemu władzy przez wykorzystanie bardziej wyrafinowanych metod rządzenia. Dzięki znacznej liberalizacji systemu powstała przestrzeń dla wysiłków zmierzających do stworzenia akceptowalnych społecznie podstaw teoretycznych krzepnącego ustroju. Dzięki temu fundamenty państwa socjalistycznego nie opierałyby się wyłącznie na brutalnej sile i aparacie przymusu. We wspomniane próby wpisywała się adaptacja osiągnięć dyscyplin naukowych, mogących okazać się użytecznymi w procesie budownictwa

tak zwanego realnego socjalizmu, w którym można wyróżnić dwa podstawowe podokresy: rządy Władysława Gomułki oraz Edwarda Gierka. Był to czas poszukiwania własnej drogi do socjalizmu przy jednoczesnym stopniowym wzroście kontestacji istniejącego ustroju; 3) lata 1981-1989 — stopniowa erozja systemu, zapoczątkowana desperacką próbą powrotu kierownictwa PZPR do siłowego rozwiązywania problemów wewnętrznych w kraju, a zakończona rezygnacją przez komunistów z dotychczasowego monopolu sprawowania władzy, procesu, za którego symboliczny koniec uznaje się wybory 4 czerwca 1989 roku. Wspomniane okresy różniły się w sposób zasadniczy od siebie, dlatego uzasadnione jest ich odrębne badanie. Po drugie, okres „stalinowski” to czas próby bezkrytycznej implementacji rozwiązań sowieckich w Polsce. Z kolei od 1981 roku, po ostatecznym bankructwie systemu, zaczęto w szerokim zakresie korzystać z wzorców zachodnich. Tymczasem lata 1956-1981 to czas, kiedy podejmowano jeszcze próby tworzenia rozwiązań stanowiących przejaw wiary w budowę ,,socjalizmu z ludzką twarzą”. „Dojrzały” PRL to zatem bardzo interesujący obszar eksploracji historycznej, w którym warto podejmować badania zmierzające do zrekonstruowania interesujących i oryginalnych koncepcji powstających na styku myśli polityczno-prawnej i myśli organizatorskiej w warunkach ograniczonej wolności badań naukowych.

${ }^{4}$ Ze względu na główny cel artykułu — próbę rekonstrukcji jednego z przypadków wpływu ideologii na koncepcje teoretyczne tworzone w obszarze nauk praktycznych w okresie ,realnego socjalizmu" - poza zakresem rozważań znalazły się takie zagadnienia, jak: 1) analiza problematyki teorii organizacji i zarządzania jako obszaru aktywności naukowej w PRL; 2) zinstytucjonalizowane formy uprawiania namysłu teoretycznego nad problemami organizacji, takimi jak działalność: Towarzystwa Naukowego Organizacji i Kierownictwa, Komitetu Naukowego Organizacji i Kierownictwa PAN, jak też struktur PZPR zajmujących się problematyką organizacji i zarządzania; 3) oficjalne deklaracje ideologiczne PZPR; 4) analiza prób implementacji rozwiązań sowieckich w zakresie organizacji i kierowania w latach 1944-1956; 5) proces uniezależniania się nauk o organizacji i zarządzaniu od wpływów ideologicznych marksizmu i stopniowego dryfowania w stronę koncepcji oferowanych przez naukę zachodnią, który zaczął nasilać się w latach siedemdziesiątych i osiągnął apogeum w latach osiemdziesiątych XX wieku.

5 A. Walicki, Dwa spojrzenia ,ex post”. Część druga - 1990, [w:] idem, Zniewolony umyst po latach, Warszawa 1993, s. 279-285.

Studia nad Autorytaryzmem i Totalitaryzmem 41, nr 4, 2019

(C) for this edition by CNS 
socjalistycznego. Pośród nich znalazły się: prakseologia, cybernetyka ${ }^{6}$, teoria systemów, nauka administracji oraz nauka organizacji i zarządzania ${ }^{7}$.

Próby implementacji osiągnięć naukowych na płaszczyznę myślenia politycznego uzasadniano między innymi tym, że:

Socjalizm nie zaczyna się wraz z chwilą obalenia formacji kapitalistycznej i przejęcia władzy przez klasę robotniczą. Zwycięstwo rewolucji stwarza jedynie warunki umożliwiające budowę społeczeństwa socjalistycznego. Aby warunki te zostały wykorzystane w sposób pełny i prawidłowy, aby koncepcje społeczeństwa klasowego nie odradzały się uporczywie w niekończącej się liczbie szczegółowych rozwiązań organizacyjnych, należy wypracować bądź rozwiązania od podstaw nowe, bądź dochodzić do nich przez redefiniowanie ukształtowanych w okresie przedsocjalistycznym pojęć przyjętych w naukach organizacyjnych ${ }^{8}$.

Pomysłom zaliczanym do teoretycznych podstaw organizowania przypisano zatem rolę ważnego instrumentu służącego operacjonalizacji ideologii na gruncie praktycznym ${ }^{9}$.

W ówczesnej nauce podkreślano wieloznaczność pojęcia „organizacja socjalistyczna”. Według Witolda Kieżuna w znaczeniu rzeczowo-atrybutywnym „organizacja jest to celowy system, którego sposób uporządkowania polega na tym, że poszczególne części współprzyczyniają się do powodzenia całości, a więc do osiągnięcia celu całości" ${ }^{\prime 10}$. Z uwagi na obszerny zbiór desygnatów autor zawęził pojęcie do takiej kategorii bytów zorganizowanych, których integralnym elementem są ludzie. Za istotną cechę takich organizacji uznał także jej interakcję z otoczeniem. Kieżun, precyzując stanowisko, wykorzystał elementy teorii systemów, cybernetyki oraz dialektyki. Stwierdził: „Mówiąc o funkcjonowaniu systemu, należy zwrócić uwagę na dialektyczną zasadę wszechzwiązku rzeczy, głoszącą, że wszystko znajduje się we wzajemnym związku i we wzajemnym oddziaływaniu"11. Oskar Lange uznał pojęcie całości jako jedną z najważniejszych idei materializmu dialektycznego, eksponującego powiązania między elementami układu oraz zależności przyczynowo skutkowe ${ }^{12}$.

${ }^{6}$ M. Mazur, Pojęcie systemu i reguty jego stosowania, „Przegląd Organizacji” 1976, nr 12, s. $501-504$.

7 W nauce polskiej doby PRL funkcjonowały również takie określenia, jak: „nauka organizacji i kierownictwa”, „nauka organizacji”, „naukowa organizacja pracy”, „nauka kierownictwa”, „teoria organizacji”. Różnice wynikały z odmiennego rozłożenia akcentów przez poszczególnych autorów. Por. T. Pszczołowski, op. cit., s. 130-131, 248-249.

${ }^{8}$ S. Kowalewski, B.R. Kuc, Stowo wstępne, [w:] Socjalistyczna teoria organizacji. Koncepcje - kierunki, red. S. Kowalewski, Warszawa 1977, s. 7; zob. też C. Miłosz, Zniewolony umyst, Warszawa 2008, s. 83.

9 Por. J. Zieleniewski, Nauki o organizacji i kierowaniu a praktyka działania, „Przegląd Organizacji” 1976, nr 4-5, s. 127-128.

10 W. Kieżun, Elementy socjalistycznej nauki o organizacji i zarządzaniu, Warszawa 1978, s. 13.

11 Ibidem, s. 15.

12 O. Lange, Całość i rozwój w świetle cybernetyki, Warszawa 1962, s. 9. 
Z kolei Jerzy Kurnal posługiwał się określeniem „nauka organizacji i zarządzania", które rozumiał jako rodzaj praktycznego działania człowieka oraz wyodrębnioną dziedzinę naukową. Podkreślał przy tym, iż:

Dodając określenie „socjalistyczna”, chcemy podkreślić, że [...] chodzi o działalność nie tylko prowadzoną w instytucjonalnych ramach ustroju socjalistycznego, ale [...] służącą interesom i potrzebom utrwalenia i rozwoju socjalistycznych stosunków społecznych. W ten sposób działalność ta nabiera wartości ideologicznych i politycznych oraz [...] wartości wspólnych dla całej powstałej w wyniku II wojny światowej rodziny Wspólnoty Krajów Socjalistycznych. Kraje należące do tej wspólnoty są powiązane nie tylko tą samą ideologią ustroju politycznego, jaką jest marksizm-leninizm [...], ale również [...] wspólnym pniem kultury socjalistycznej ${ }^{13}$.

Podobnie zatem jak obecnie wyróżniano ówcześnie przedmiotowe, czynnościowe i atrybutywne znaczenie pojęcia „organizacja”. Natomiast przymiotnik „socjalistyczna” miał łączyć jego desygnaty z konkretną ideologią.

Chociaż w okresie PRL starano się tworzyć własny dorobek, nie odcinano się od tradycji okresu międzywojennego. Szczególnie chętnie odwoływano się do badań Karola Adamieckiego oraz jego współpracowników ${ }^{14}$. Argumentowano przy tym, że chociaż dorobek ten nie był inspirowany potrzebami gospodarki socjalistycznej, należało docenić rzetelność przedwojennych badań. Istotną rolę odgrywała tradycja Towarzystwa Naukowego Organizacji i Kierownictwa. Innym źródłem inspiracji dla myśli organizatorskiej były osiągnięcia prakseologii, której podstawy sformułował Tadeusz Kotarbiński przed II wojną światową ${ }^{15}$. Wymieniono także nauki humanistyczne. Podsumowując, należy wskazać, że w PRL uznawano ciągłość myśli organizatorskiej, zaznaczając jednak konieczność dostosowania dorobku powstałego wcześniej do warunków socjalistycznej formacji ustrojowej.

$\mathrm{Z}$ racji dominującej ideologii namysł poświęcony teoretycznym podstawom organizacji w omawianym okresie PRL jako kluczowy punkt odniesienia musiał uwzględniać założenia marksizmu-leninizmu. Poglądy wodza rewolucji wyznaczały nie tylko kierunek, ale i granice swobodnej refleksji ${ }^{16}$. Rozważania na tym

13 J. Kurnal, Polski wkład do rozwoju socjalistycznej nauki i praktyki organizacji i zarzadzania, [w:] Wpływ Wielkiej Socjalistycznej Rewolucji Październikowej i nauki radzieckiej na rozwój organizacji i zarządzania w PRL. 60-lecie Wielkiej Socjalistycznej Rewolucji Październikowej. Ogólnokrajowa konferencja naukowa, Warszawa 1977, s. 54-55.

14 Por. K. Adamiecki, O nauce organizacji. Wybór pism, Warszawa 1970; M. Zdyb, Zarys historii myśli organizatorskiej, Lublin 1987, s. 245-255; Z. Martyniak, Historia myśli organizatorskiej. Wybitni autorzy z zakresu organizacji i zarządzania w pierwszej połowie XX w., Kraków 2002, s. 81-89; W. Gogłoza, K. Księski, Historia myśli organizatorskiej. Zarys wykładu, Warszawa 2013, s. $86-95$.

15 J. Kurnal, op. cit., s. 69, 70-74; J. Woleński, Kotarbiński, Warszawa 1990, s. 7-15. Warto zaznaczyć, że w okresie „stalinowskim” prakseologia była ostro zwalczana przez reprezentantów marksizmu. Zob. L. Kołakowski, Główne nurty marksizmu. Powstanie - rozwój - rozkład, Warszawa 1988, s. 901-902.

16 Por. A. Ehrlich, Wplyw wielkiej socjalistycznej rewolucji październikowej i nauki radzieckiej na rozwój organizacji i zarządzania w PRL, [w:] Wptyw Wielkiej Socjalistycznej Rewolucji

Studia nad Autorytaryzmem i Totalitaryzmem 41, nr 4, 2019

(C) for this edition by CNS 
polu mogły być oryginalne i twórcze o tyle, o ile nie naruszały obowiązującej ideologii, a przynajmniej pozostawały wobec niej neutralne. Dla myśli organizatorskiej szczególnego znaczenia nabierało uznanie organizacji jako bytu złożonego, którego części zostały podporządkowane określonym regułom działania $\mathrm{w}$ interesie całości. Założenie to wynikało wprost $\mathrm{z}$ doktryny Marksa, który twierdził, że stosunki produkcji w państwie tworzą całość ${ }^{17}$. Podążając tym tokiem rozumowania, Lenin uznawał społeczeństwo za rozwijający się układ, w którym rolę integrującą odgrywały procesy produkcji ${ }^{18}$.

Snując millenarystyczne wizje, wódz rewolucji krytycznie oceniał pierwsze sowieckie próby na polu nauki organizacji. Z racji przypisywanego refleksji organizatorskiej znaczenia uznał za konieczne podjęcie przez bolszewików systematycznych prac w tym zakresie. Doceniając znaczenie dyscypliny, zgodził się jednocześnie na ustępstwo wobec dorobku burżuazyjnego, aby w oczekiwaniu na wdrożenie efektów rodzimych badań przetłumaczyć na język rosyjski dzieła Fredericka W. Taylora. Zabieg ten miał tymczasowo zaspokoić zapotrzebowanie praktyki na opracowania z obszaru nowoczesnej organizacji pracy w oczekiwaniu na satysfakcjonujące efekty własnych działań ${ }^{19}$.

Pomimo taktycznych ustępstw na rzecz nauki zachodniej wkrótce po rewolucji podjęto działania zmierzające do wypracowania podstaw socjalistycznej teorii organizacji. Wielu badaczy poszukiwało inspiracji własnych poglądów w Leninowskiej refleksji na temat organizacji pracy ${ }^{20}$. Z czasem nauki radziecka oraz państw bloku socjalistycznego rozwinęły własne badania w omawianym obszarze. $\mathrm{Z}$ ich dorobku korzystali marksizujący przedstawiciele polskiej nauki organizacji okresu PRL ${ }^{21}$.

Na płaszczyźnie myśli organizatorskiej inspirowanej marksizmem próbowano wykorzystać do operacjonalizacji w formie praktycznych dyrektyw zasadę dialektycznej jedności przeciwieństw. Przybierały one formę antynomii pojęć

Październikowej..., s. 85-86; Z. Zbichorski, Ksztatcenie i doskonalenie inżynierów organizatorów na tle doświadczeń ZSRR, [w:] Wpływ Wielkiej Socjalistycznej Rewolucji Październikowej..., s. 100; J. Rachwalski, Wpływ wielkiej socjalistycznej rewolucji październikowej i nauki radzieckiej na rozwój organizacji i zarzadzania w przemyśle w PRL, [w:] Wpływ Wielkiej Socjalistycznej Rewolucji Październikowej..., s. 110 n., 120-121; J. Drozdowicz, Znaczenie wielkiej socjalistycznej rewolucji październikowej dla spółdzielczości w Polsce, [w:] Wpływ Wielkiej Socjalistycznej Rewolucji Październikowej..., s. 150-151; S. Kowalewski, O ksiażkach. Podstawy marksistowskiego zarządzania i kierowania, „Przegląd Organizacji” 1978, nr 1, s. 41-42; E. Głodziński, „Przegląd organizacji” - wczoraj i dziś. Rola czasopisma w rozwoju nauk o zarządzaniu. Cz. 1, „Przegląd organizacji” 2016, nr 3, s. 73, 75.

17 K. Marks, F. Engels, Dzieła, t. 4, Warszawa 1962, s. 142.

18 W.I. Lenin, Dzieła, t. 9, Warszawa 1953, s. 371.

19 W.I. Lenin, Dzieła, t. 27, Warszawa 1957, s. 264-265.

20 W. Kieżun, op. cit., s. 40.

21 S. Kowalewski, Wykorzystanie dorobku nauki i praktyki radzieckiej w ksztaltowaniu organizacji i zarzadzania w PRL, [w:] Wpływ Wielkiej Socjalistycznej Rewolucji Październikowej..., s. 5; Idee organizatorskie W.I. Lenina, „Prakseologia” 1970, nr 36. Lenin a teoria i praktyka organizacji, s. 3-23. 
stanowiących wytyczne sprawnego działania ${ }^{22}$. Były to: 1) specjalizacja-uniwersalizacja; 2) aktywizacja-ograniczenie działania; 3) kunktacja-antycypacja, 4) utrzymanie rezerw zasobów-pełne wykorzystanie zasobów, 5) koncentracja sił-zabezpieczenie wszystkich kierunków działania ${ }^{23}$.

Powołując się na autorytet Lenina, badacze stojący na gruncie marksizmu twierdzili, że u podstaw poglądów wodza rewolucji na temat organizacji pracy leżała troska o godność i interes człowieka. Idee te miały zmaterializować się w praktyce dzięki ograniczaniu zjawiska alienacji jednostki i eksponowaniu znaczenia współdziałania, a także trosce o realizację celów społecznych ${ }^{24}$. W kręgu inspiracji znalazł się model piramidy potrzeb Maslowa ${ }^{25}$. Poszukujący uzasadnienia etycznego dla formowanego porządku Stanisław Ossowski wskazywał, że idea rozwoju indywidualnego oraz pełne wyzyskanie potencjału twórczego jednostki uzyskuje szczególnie korzystną stymulację dzięki zastosowaniu demokratycznego modelu organizacji pracy ${ }^{26}$.

$\mathrm{Z}$ uwagi na to, że praca była w PRL nie tylko uprawnieniem, lecz także obowiązkiem (art. 14 Konstytucji PRL), istotnego znaczenia nabierało zdefiniowanie wzorca osobowego pracownika. Ów wzorzec pokrywał się znacząco z wizją człowieka socjalistycznego. Ponieważ środowisko pracy stanowiło podstawowe miejsce, w którym jednostka dzięki socjalizacji miała stawać się integralnym elementem społeczeństwa socjalistycznego, było to główne pole, na którym dążono do przekształcenia ,psychiki indywidualnej w psychikę społeczną”. Celowi temu służyło wyrabianie poczucia współodpowiedzialności za zakład pracy, co z kolei wiązało się z ustrojową zasadą ochrony uspołecznionych środków produkcji (art. 8 Konstytucji PRL).

Postulat akceptacji prymatu interesu społecznego wpisywał się w socjalistyczny wzorzec osobowy oraz nawiązywał do tradycji humanizmu. Do podstawowych cech opartej na tych założeniach etyki socjalistycznej zaliczono: 1) akceptację wartości moralnych ukształtowanych w historycznym rozwoju ludzkości; 2) nacisk na wartości wynikające z ideologii socjalistycznej, w tym idei postępu. Przyjęcie tych założeń skutkowało przesunięciem refleksji etycznej z jednostki na zespoły, grupy, klasy i organizacje, prowadząc do ich swoistej antropomorfizacji 27. Podkreślano, że pojęcie wychowującego społeczeństwa było implicite zawarte $\mathrm{w}$ teorii materializmu dialektycznego i historycznego ${ }^{28}$. Formowaniu nowego

22 W. Kotarbiński, Wybór pism, t. 1. Myśli o działaniu, Warszawa 1957, s. 623, 658.

23 W. Kieżun, op. cit., s. 29-31.

24 Ibidem, s. 48-49.

25 A.H. Maslow, Motywacja i osobowość, przeł. J. Radzicki, Warszawa 2013, s. 62 n.

26 S. Ossowski, Ku nowym formom życia społecznego, Warszawa 1966, s. 16-17.

27 W. Kieżun, op. cit., s. 198-203; A. Podgórecki, Patologia działania instytucji, [w:] Socjotechnika. Funkcjonalność i dysfunkcjonalność instytucji, red. A. Podgórecki, Warszawa 1974, s. 49-50.

28 W. Kieżun, op. cit., s. 44; S. Kowalewski, Wybrane elementy socjalistycznej teorii organizacji i nauki o administrowaniu, [w:] Socjalistyczna teoria..., s. 13; C. Czapów, Socjotechnika 
człowieka, człowieka socjalistycznego, miało służyć wykorzystanie narzędzi socjotechnicznych $^{29}$.

\section{Założenia koncepcji organizacji socjalistycznej}

Reprezentanci nurtu marksistowskiego w polskiej nauce organizacji doby PRL uwzględniali dynamiczny rozwój myśli organizatorskiej w XX wieku, przy czym za szczytowe jej osiągnięcie uznawali socjalistyczną gospodarkę planową ${ }^{30}$. Chętnie korzystali również z dorobku innych dyscyplin. Przydatne okazały się wyniki badań cybernetyki ${ }^{31}$, teorii decyzji, teorii systemów oraz prakseologii ${ }^{32}$. Stopniowo wzrastało zainteresowanie informatyzacją. Podkreślali także inspirację historyczną ${ }^{33}$. Szczególnie wyraźnie rysowało się, mające źródło w tradycji oświeceniowej, przekonanie o potędze ludzkich możliwości oraz mocy kreowania rzeczywistości.

W marksistowskiej teorii „Praxis” człowiek nie stoi wobec gotowego świata przedmiotów — świata, który miałby być tylko przedmiotem kontemplacji i rozważań. Aby zająć w tym świecie należne miejsce, aby posiąść należną sobie moc, potęgę, musi człowiek zajmować wobec otaczającego świata (a dzięki temu także wobec samego siebie) właśnie rewolucyjną praktyczno-krytyczną postawę

Najlepszym sposobem potwierdzenia prawdziwości teorii naukowych miała być ich przydatność praktyczna ${ }^{35}$. Jako dowód wyższości socjalistycznej nauki organizacji nad osiągnięciami „nauki burżuazyjnej” wskazywano budowę Pałacu Kultury i Nauki w Warszawie ${ }^{36}$.

Budowana na fundamencie marksizmu-leninizmu rodzima koncepcja organizacji socjalistycznej odznaczała się szczególną specyfiką, odróżniającą ten rodzaj myślenia o uporządkowanych działaniach zespołowych od klasycznego modelu w zaktadzie pracy, Warszawa 1975, s. 38-40; W. Wiecki, Administracja publiczna a rozwój kultury, [w:] Socjalistyczna teoria..., s. 79 n.

29 W. Kieżun, op. cit., s. 205-206.

30 Ibidem, s. 9.

31 J. Kurnal, op. cit., s. 78-80; zob. R. Kania, Rozvitokpravovoï kibernetiki u Pol'sì v HHmustoriččc̀, „İnformaciâì Pravo Naukovij Fahovij Žurnal” 2018, nr 1, s. 81-88; idem, Marksizm-leninizm a cybernetyka prawa w PRL. Zarys problematyki, „Miscellanea Historico-Iuridica” 16, 2017, nr 1, s. 153-170.

32 W. Kieżun, op. cit., s. 11; J. Kurnal, Przydatność prakseologicznej aparatury pojęciowej dla badań nad organizacja przedsiębiorstw handlowych, [w:] Przydatność prakseologicznej aparatury pojęciowej dla poszczególnych dyscyplin naukowych, red. T. Kotarbiński et al., Wrocław-Warszawa 1964, s. 41 n; A. Matejko, Przydatność prakseologicznej aparatury pojęciowej dla teorii systemów społecznych, [w:] Przydatność prakseologicznej aparatury..., s. 61 n.

33 W. Kieżun, op. cit., s. 57.

34 M. Holstein-Beck, Problemy kierowania postępem, [w:] Socjalistyczna teoria..., s. 125.

35 Filozofia marksistowska, red. J. Grudzień et al., Warszawa 1978, s. 138-154.

36 W. Kieżun, op. cit., s. 89. 
organizacji kapitalistycznej. Źródeł tej odmienności upatrywano w uwarunkowaniach charakteryzujących socjalistyczną formację społeczną: jej celów, uspołecznionej formy własności i centralnego planowania. W sposób zbliżony do założeń teorii systemó $w^{37}$ zakładano, że każda organizacja powinna stanowić element składowy złożonego systemu społeczno-gospodarczego państwa, będąc integralnym elementem funkcjonalnym tej całości. Podkreślano, że wzajemne powiązanie stymulował rozszerzający się katalog zadań państwa socjalistycznego ${ }^{38}$.

Państwu socjalistycznemu stawiano szczególne cele. Jako makroorganizacja musiało ono nie tylko sprostać przyspieszeniu rozwoju wynikającego z dynamicznego postępu technicznego, lecz także zmierzyć się z problemami powstającymi na drodze doskonalenia socjalistycznej formacji ustrojowej ${ }^{39}$. Kwestię tę interpretowano zgodnie z założeniami materializmu historycznego ${ }^{40}$. Na przykład Oskar Lange zauważył, iż zmiana w nadbudowie postępuje znacznie wolniej niż przemiany na poziomie środków produkcji ${ }^{41}$. Dlatego dojście od kapitalizmu do rozwiniętego ustroju socjalistycznego wymagało wypracowania nowych pojęć, idei i sposobu myślenia. Konstanty Piłejko z kolei zwracał uwagę na niemożliwość bezpośredniego dojścia do komunizmu z pominięciem etapów pośrednich. Problem dodatkowo komplikowało niewypracowanie wzorca organizacji socjalistycznej przez klasyków marksizmu. Z tego względu dostrzegano pilną potrzebę budowy modelu organizacji socjalistycznej, opierając się na syntezie dialektyki i prakseologii. Stosownie do dynamicznego charakteru marksizmu-leninizmu owa koncepcja powinna być zmienna w czasie. Potrzebę budowy takiego modelu łączono z poglądem o podleganiu organizacji procesowi dialektycznego rozwoju i wynikającej stąd ciągłej przemianie jako efekcie nieustannej walki przeciwieństw. Jednocześnie nowy, technokratyczny język opisu ustroju państwa próbowano łagodzić odwołaniem do wartości ogólnoludzkich. Pośród cech odróżniających nową organizację socjalistyczną od jej kapitalistycznego odpowiednika szczególnego znaczenia nabierały humanistyczne aspekty działań zespołowych ${ }^{42}$.

Koncepcja organizacji socjalistycznej uwzględniała marksistowską ideę całościowości. Baza i nadbudowa stanowiły koherentne elementy, będące wynikiem stosunków społeczno-gospodarczych panujących na danym etapie rozwoju cywilizacyjnego. System ten, jako zjawisko dynamiczne, należało postrzegać w ruchu i ciągłej przemianie ${ }^{43}$. Synteza przeciwieństw miała stymulować rozwój i doskonalenie form organizacyjnych bytu ludzkiego. Dzięki uchwyceniu i skontrolowaniu

37 Por. L. Bertalanffy, Ogólna teoria systemów. Podstawy, rozwój, zastosowania, przeł. E. Woydyłło-Woźniak, Warszawa 1984, s. 223 n.

38 K. Piłejko, Model organizacji w ustroju socjalistycznym, Warszawa 1969, s. 5-6; Organizacja społeczeństwa socjalistycznego w Polsce, red. A. Łopatka, Warszawa-Poznań 1968, s. 19-23.

${ }^{39}$ Ibidem, s. 8-9.

40 A. Schaff, Wstęp do teorii marksizmu, Warszawa 1948, s. 165 n.

41 O. Lange, Ekonomia polityczna, t. 1, Warszawa 1961, s. 172.

42 K. Piłejko, op. cit., s. 10-13.

43 A. Schaff, op. cit., s. 73 n. 
wspomnianych prawidłowości organizacja socjalistyczna powinna stanowić system świadomie i celowo powiązanych elementów. Racjonalny namysł miał natomiast prowadzić do podniesienia skuteczności osiąganych celów państwa oraz jego części składowych ${ }^{44}$.

Nawiązując do założeń teorii systemów ${ }^{45}$ pozwalających ujmować organizację państwową holistycznie ${ }^{46}$, wyróżniono dwa poziomy analizy: 1) makroorganizację, czyli państwo jako całość; 2) mikroorganizacje, czyli poszczególne części systemu pełniące funkcję elementów składowych makroorganizacji. Przyjęcie perspektywy makrosystemowej miało dać kompletny obraz państwa. U podstaw jego koherentnej wizji leżała harmonia i współdziałanie, wsparte praworządnością socjalistyczną ${ }^{47}$. Spójność poszczególnych elementów całości była osiągalna, gdyż funkcjonowanie organizacji socjalistycznej miało odbywać się w sposób planowy na wszystkich poziomach ${ }^{48}$. Kluczową rolę przypisywano centralnym władzom państwa, zajmowanym w praktyce przez kierownictwo PZPR. Podkreślano przy tym, że spójność nie jest możliwa w ustroju kapitalistycznym, w którym wzajemne relacje mikroorganizacji opierają się na rywalizacji (kooperacja negatywna $)^{49}$. Wyższość rodzimych rozwiązań wywodzono z rzekomych walorów polityki socjalistycznej, charakteryzującej się przyjmowaniem szerszych horyzontów czasowych i przestrzennych, wykraczających poza proste rozumowanie w kategoriach zysków i strat właściwych podmiotom działającym w warunkach konkurencji wolnorynkowej ${ }^{50}$. Przyjmując takie założenia, usiłowano uzyskać zamkniętą, spójną i przewidywalną wizję państwa.

Z koncepcją spójnej, sterowalnej całości łączyła się zasada jedności kierownictwa. Dzięki temu rozwiązaniu kierujący mikroorganizacjami, będący związani odgórnymi dyrektywami, nie byli samodzielni. Kierowane do nich wytyczne miały charakter polityczny i organizacyjny. Rozwiązanie to korespondowało z konstytucyjną ideą jedności władzy (art. 15 Konstytucji PRL). Na szczeblu najwyższym zapadały decyzje dotyczące celów i zadań oraz zasobów niezbędnych do

${ }^{44}$ K. Piłejko, op. cit., s. 22-24; idem, Dialektyka w organizacji, „Prakseologia” 1970, nr 36, s. $91 \mathrm{n}$.

45 K. Piłejko, Model..., s. 34-35; S. Kwiatkowski, Modele myślenia organizacyjnego, „Przegląd Organizacji” 1976, nr 1, s. 3; A. Aranowski, Koncepcja systemu ekonomicznego — podejście organizacyjne, „Przegląd Organizacji” 1976, nr 1, s. 4.

46 Organizacja spoleczeństwa..., s. 14-16, 17-18.

47 Por. S. Kowalewski, Stowo..., s. 10-12; K. Opałek, W. Zakrzewski, Z zagadnień praworządności socjalistycznej, Warszawa 1958, passim.

48 M. Mielnik, Metody oceny efektywności działalności wielkich organizacji produkcyjnych, „Przegląd Organizacji” 1977, nr 10, s. 447.

49 K. Piłejko, Model..., s. 25-26, 32; W. Kieżun, op. cit., s. 105-120, 143-144; J. Zieleniewski, Organizacja zespołów ludzkich, Warszawa 1964, s. 44; J. Drecin, Socjalistyczna polityka gospodarcza a zarządzanie przedsiębiorstwami, „Przegląd Organizacji” 1976, nr 3, s. 82.

50 S. Kowalewski, Wybrane elementy..., s. 21. 
ich realizacji. Akceptowano, że w praktyce decyzje centralnego ośrodka władzy bezpośrednio wpływały na wszystkie mikroogranizacje systemu ${ }^{51}$.

Odgrywając rolę służebną, części składowe systemu miały być zawsze postrzegane w kontekście celów całości; podobnie do Arystotelesowskiej idei pierwotności polis wobec wiosek, rodzin i człowieka ${ }^{52}$ reprezentanci koncepcji organizacji socjalistycznej uznawali pierwszeństwo państwa wobec jego podsystemów. Uznawano przy tym, że całość jest czymś więcej niż tylko prostą sumą części, gdyż racjonalne powiązanie elementów składowych i wspólnota celów powodowały efekt synergii ${ }^{53}$.

Analiza każdej instytucji powinna prowadzić od jej oceny całościowej, poprzez kolejne poziomy, na stanowisku pracy kończąc. Każdy podsystem organizacji rozpatrywany miał być w szerszym kontekście wpływu na państwo - uzyskanie szerszej perspektywy pozwalałoby bowiem wyeliminować szkodliwe zjawisko suboptymalizacji. Dzięki takiemu rozwiązaniu każde działanie wpisywałoby się w przyjętą centralnie wizję racjonalności ogólnospołecznej ${ }^{54}$. W takim wypadku miarą powodzenia każdej instytucji stawał się wynik relacji dwóch parametrów: tego, co otrzymuje od społeczeństwa, oraz tego, co społeczeństwu daje. Podstawą oceny instytucji nie byłaby korzyść indywidualna, lecz jej udział w kreowaniu dobra społecznego ${ }^{55}$. Preferowano zatem kryterium utylitarne i ogólnospołeczne.

Przyjęcie dialektycznej jedności przeciwieństw ${ }^{56}$ prowadziło do konstatacji, że przekształcenia organizacji w ustroju socjalistycznym stanowiły efekt sprzeczności ujawniających się $\mathrm{w}$ działaniu. Ich kumulacja wymuszała wprowadzanie zmian korygujących funkcjonowanie systemu, co powodowało jego przejście na wyższy poziom rozwoju. Reprezentanci koncepcji organizacji socjalistycznej uważali sprzeczności i konflikty za cechy immanentne i jednocześnie korzystne dla zorganizowanego działania ludzkiego ${ }^{57}$. Wskazywano przy tym trzy skutki oddziaływania dialektyki na organizację: 1) przechodzenie od struktur prostych do bardziej złożonych; 2) cykliczność rozwoju; 3) powtarzalność powstawania sprzeczności na każdym etapie rozwoju ${ }^{58}$. Historyczne ujęcie tych procesów uznawano za szczególną zdobycz teoretyczną „socjalizmu naukowego", który uwypuklał konieczność nieustannego dostosowania form ustrojowych

51 K. Piłejko, Model..., s. 36-38; S. Kwiatkowski, Modele myślenia..., s. 2; A. Sarapata, Rozwój spoleczeństwa socjalistycznego — zakład pracy — kadra kierownicza, „Przegląd Organizacji” 1976, nr 4-5, s. 175-177.

52 Arystoteles, Polityka, przeł. L. Piotrowicz, Warszawa 1964, s. 8.

53 K. Piłejko, Model..., s. 55-56; H. Sadownik, Cele organizacji gospodarczej, „Przegląd Organizacji” 1976, nr 7, s. 270.

54 K. Piłejko, Model..., s. 39; S. Kowalewski, Pojęcie powodzenia instytucji (przyczynek do socjalistycznej teorii organizacji), „Przegląd Organizacji” 1977, nr 1, s. 18.

55 S. Kowalewski, Wybrane elementy..., s. 17-18.

56 W. Lenin, Zeszyty filozoficzne, Warszawa 1956, s. 336.

57 K. Piłejko, Model..., s. 50.

58 Ibidem, s. 52-53. 
i organizacyjnych, a więc nadbudowy, do zmieniających się stosunków i środków produkcji, czyli bazy ${ }^{59}$.

Teoretycy nurtu uważali, że specyfika organizacji socjalistycznej nie wynikała ze szczególnej pozycji idei pracy, lecz warunków, w których była ona wykonywana. Zmienność form organizacyjnych wynikała ze stymulowanego przez państwo postępu technicznego oraz ewolucji formacji socjalistycznej. Różnorodność rozwiązań stosowanych w praktyce uzasadniano obieraniem różnych dróg rozwoju, prowadzących jednak ostatecznie do tego samego celu — rozwiniętego społeczeństwa socjalistycznego. Zauważyli, że trudności poszukiwania uniwersalnego modelu organizacji socjalistycznej wynikały z tego, że w przeciwieństwie do socjalistów utopijnych twórcy „socjalizmu naukowego" dalecy byli od jednoznacznego definiowania chiliastycznej wizji doskonałego społeczeństwa ${ }^{60}$. W konsekwencji określony jedynie mgliście cel kierownictwa politycznego nie ułatwiał zadania postawionego przed teoretykami organizacji.

Nieopracowanie wzorca organizacji socjalistycznej przez klasyków marksizmu skutkowało względną dowolnością tworzonych koncepcji, oczywiście w gra nicach poprawności ideologicznej. Przytaczano pogląd Lenina, że im więcej zostanie wygenerowanych pomysłów, tym szybciej zostanie zrealizowany ideał centralizmu demokratycznego oraz gospodarki socjalistycznej ${ }^{61}$. Reprezentanci nurtu podkreślali, że przestrzeń do tworzenia konkurencyjnych koncepcji organizacji socjalistycznej powstała wraz z „destalinizacją” oraz odrzuceniem kultu jednostki. W atmosferze względnej liberalizacji pozwolono sobie nawet na krytyczne uwagi. Dostrzegano szkodliwość nadmiernej koncentracji władzy na najwyższym szczeblu organizacyjnym, co miało stanowić asumpt do poszukiwania optymalnych proporcji między centralizacją a decentralizacją władzy w Polsce ${ }^{62}$.

Konstruując model organizacji socjalistycznej, badacze wykorzystali Leninowski pogląd o nieprawidłowościach pojawiających się w praktyce funkcjonowania państwa socjalistycznego. Pośród najważniejszych wymieniano: 1) biurokratyzację; 2) rozproszenie i dekoncentrację działań; 3) pochopne przeprowadzanie reorganizacji; 4) błędy w doborze kadr; 5) brak wewnętrznego ładu oraz marnotrawstwo czasu; 6) rytualizację tradycyjnych konwencji urzędniczych. Ponadto, nawiązując do prawa Parkinsona ${ }^{63}$, wskazywano na postępującą inflację sztucznie wykreowanych działań oraz szkodliwość zjawiska autonomizacji celów mikroorganizacji ${ }^{64}$.

\footnotetext{
59 Ibidem, s. 58.

60 W. Lenin, Dzieła, t. 27, s. 428.

61 Ibidem, s. 210.

62 K. Piłejko, Model..., s. 47-48, 49.

63 C.N. Parkinson, Prawo Parkinsona, przeł. J. Kydryński, Warszawa 1964, s. 11 n.

64 W. Kieżun, op. cit., s. 266-270, 272-273; zob. też A. Ehrlich, op. cit., s. 94-98.
} 


\section{Cechy organizacji socjalistycznej}

Specyfika koncepcji organizacji socjalistycznej wynikała z kilku charakterystycznych dla niej cech. Poza wpisywaniem się wszystkich elementów jednostkowych w metasystem oraz podleganie zarówno całości, jak i części procesu dialektycznego rozwoju na pierwszy plan wysuwała się realizacja celu nadrzędnego - budownictwa socjalistycznego. W piśmiennictwie eksponowano zintegrowany charakter realizowanych zadań, w szczególności wszechstronny rozwój państwa, obejmujący domenę polityczną, gospodarczą i społeczną. Argumentowano, że dokładne zdefiniowanie każdego celu i zadania na wszystkich szczeblach struktury państwa stanowi warunek sine qua non racjonalnego działania, a ich spójność ułatwiała wspólne podążanie w jednym kierunku. Nie było już miejsca na interesy partykularne. Dlatego za Leninem odrzucano zysk jako główny cel przedsiębiorstw. Zgodnie z założeniami ideologicznymi ustroju prymat zyskiwało dobro wspólne oraz wpisujący się w kolektyw człowiek socjalistyczny i jego wszechstronny rozwój. Sposób pojmowania celów wiązał się zatem ściśle z deklarowanym przez marksizm systemem wartości i dialektyczną teorią rozwoju społecznego ${ }^{65}$.

Powiązanie celów mikroorganizacji z celami państwa nie wydawało się teoretykom nurtu nadmiernie kłopotliwe, gdyż zgodnie z przyjętymi założeniami były one koherentne. Za Marksem i Engelsem ${ }^{66}$ eksponowano praktyczny cel istnienia państwa, za który uznano podniesienie materialnego poziomu życia obywateli. Przyjmując tak sformułowany cel na poziomie najwyższym, uważano, że powinny mu zostać podporządkowane wszystkie cele na niższym poziomie organizacyjnym. Integrację miało ułatwić centralne planowanie gospodarki narodowej. Planowości na poziomie centralnym miała odpowiadać planowość na każdym szczeblu hierarchii systemu. Na najniższym poziomie szczególna rola, jako realizatorom zadań podstawowych, przypadała zakładom pracy ${ }^{67}$. Należy jednak dodać, że planowości państwowej nie utożsamiano z wąskim obszarem wzrostu ekonomicznego. Nawiązując do humanistycznych deklaracji marksizmu, podkreślano bowiem znaczenie celów pozaekonomicznych ${ }^{68}$.

Cechą o kluczowym znaczeniu dla specyfiki organizacji socjalistycznej był społeczny charakter środków produkcji. W świetle ideologii marksistowskiej

65 K. Piłejko, Model..., s. 60; W. Kieżun, op. cit., s. 57, 59; por. S. Kowalewski, Wykorzystanie dorobku nauki i praktyki radzieckiej $w$ ksztaltowaniu organizacji i zarzadzania $w$ PRL, [w:] Wpływ Wielkiej Socjalistycznej Rewolucji Październikowej..., s. 6 n.

66 K. Marks, F. Engels, Dzieła wybrane, t. 1, Warszawa 1949, s. 440.

67 S. Kowalewska, Psychospołeczne warunki pracy w przedsiębiorstwie przemysłowym. Studium o systemie społecznym socjalistycznego przedsiębiorstwa, Warszawa 1962, s. 46; Socjologiczne problemy przedsiębiorstwa przemystowego, red. A. Sarapata, Warszawa 1965, s. 8, 10, 15; J. Lutosławski, Człowiek w przedsiębiorstwie przemysłowym, Warszawa 1960, s. 106; K. Piłejko, Model..., s. 77.

68 K. Piłejko, Model..., s. 61-63, 65, 71-72. 
uspołecznienie środków produkcji stanowiło jedną z fundamentalnych idei ówczesnej formacji ustrojowej. O jej znaczeniu świadczy fakt, że w ustroju PRL uzyskała ona status zasady konstytucyjnej (art. 8 Konstytucji PRL) — na jej podstawie formułowano dyrektywy praktyczne organizacji państwa, społeczeństwa i gospodarki ${ }^{69}$, wpływała ona też na rozwój nowej świadomości i postawy społecznej człowieka socjalistycznego. Własności uspołecznionej miał odpowiadać nowy, odmienny od kapitalistycznego, model racjonalności społeczno-gospodarczej. Zdawano sobie przy tym sprawę z niebezpieczeństwa błędnego pojmowania istoty własności społecznej jako szczególnego rodzaju współwłasności, co groziło jej wykorzystywaniem do realizacji partykularnych interesów przez dysponujących nią posiadaczy ${ }^{70}$. Z tego powodu podkreślano powszechność obowiązku zachowania szczególnej dbałości o własność społeczną, podnosząc ten obowiązek do rangi konstytucyjnej (art. 77 Konstytucji PRL).

W koncepcji organizacji socjalistycznej ważna rola przypadała jednostkom. Czynna rola człowieka w procesie budownictwa socjalistycznego skutkowała uznaniem rozwoju indywidualnego za kluczowy cel tej formacji ustrojowej. Było to oczywiście doskonalenie pojmowane zgodnie z obowiązującą ideologią. Uważano, że każdy człowiek powinien zaangażować się w budowę nowego porządku ze względu na osobistą motywację. Znaczenia nabierał demokratyczny model kierownictwa na wszystkich szczeblach hierarchii organizacyjnej ${ }^{71}$.

W teorii wszechstronne doskonalenie człowieka traktowano jako warunek sine qua non rozwoju ustroju socjalistycznego. Zgodnie z założeniami marksizmu przyjmowano, że człowiek osiąga pełnię przyrodzonych możliwości dopiero w sprzyjających warunkach tworzonych przez wspólnotę ${ }^{72}$. W kreowanej wizji istotna rola przypadła socjalistycznej aksjologii eksponującej wartość wysiłku i osiągnięć uzyskanych na drodze samodoskonalenia. Naturalną konsekwencją tego stanowiska było podniesienie pracy do rangi wartości najwyższej. Aktywność zawodowa miała stanowić źródło satysfakcji oraz podstawę uznania społecznego ${ }^{73}$.

Wraz z eksponowaniem roli jednostki aktualna stała się potrzeba stworzenia adekwatnej koncepcji psychologicznej ludzkiej osobowości. Model człowieka ekonomicznego zastąpiono w związku z tym modelem człowieka uspołecznionego (homo socialis) ${ }^{74}$. Człowiek socjalistyczny powinien przezwyciężać egoizm i konsumpcjonizm właściwy formacji kapitalistycznej oraz wykazywać się

69 Ibidem, s. 88-89, 97.

70 A. Podgórecki, Socjologia prawa, Warszawa 1962, s. 104.

${ }^{71}$ K. Piłejko, Model..., s. 99-102.

72 K. Marks, F. Engels, Dzieła wybrane, t. 3, Warszawa 1949, s. 83.

73 K. Piłejko, Model..., s. 104; S. Kowalewski, Samorealizacji w świetle światopogladu marksistowskiego (przyczynek do socjalistycznej teorii organizacji), „Przegląd Organizacji” 1976, nr 12, s. 507-509.

74 B.R. Kuc, Warunki efektywnej samokontroli, [w:] Socjalistyczna teoria..., s. 159. 
altruizmem i bezinteresownym oddaniem na rzecz wspólnego dobra ${ }^{75}$. Wizja ta była interpretowana zgodnie z dialektycznym łączeniem sprzeczności. Zakładano, iż w ustroju socjalistycznym człowiek zostanie pobudzony do aktywności przy jednoczesnym opanowaniu jego naturalnej żywiołowości przez narzucenie dyscypliny pracy oraz obowiązku realizacji zadań wyznaczonych przez państwo. Temu celowi miała służyć przemyślana polityka kadrowa ${ }^{76}$.

Kreując idealny wzorzec obywatela, zakładano prymat skuteczności motywacyjnej bodźców psychicznych nad materialnymi. Wiązano z tym konieczność gotowości jednostki do posłuszeństwa woli przełożonych. Osiągnięcie oczekiwanych postaw indywidualnych miały ułatwić wspomniany już model kierownictwa demokratycznego oraz stopniowe niwelowanie postaw egoistycznych wraz z pelniejszym zaspokojeniem potrzeb ogólnospołecznych przez państwo socjalistycz$\mathrm{ne}^{77}$. Polscy badacze nawiązywali do stanowiska Lenina, którego zdaniem świadome podporządkowanie jednostek przełożonym powinno przypominać łagodne kierownictwo dyrygenta. Jednocześnie jednak, zgodnie z wieloznacznościami i sprzecznościami charakteryzującymi poglądy wodza rewolucji, dopuszczono, aby kierowanie przybierało ostre formy dyktatury, jeżeli tego wymagałyby okoliczności ${ }^{78}$. W ten sposób implicite usprawiedliwiano dowolność metod kierowania, dostosowywanych do potrzeb rządzących.

Teoretycy organizacji socjalistycznej podkreślali znaczenie kolektywizmu. Znajdowali dla tej idei dwojakie uzasadnienie. Po pierwsze, była ona jednym z podstawowych dogmatów marksizmu, a po drugie, współdziałanie stanowiło warunek sprawnej realizacji celów. Uzasadnienie miało zatem nie tylko wymiar ideologiczny, lecz także prakseologiczny. Kotarbiński, uznawany ówcześnie za niekwestionowany autorytet, właśnie w powstaniu kolektywów upatrywał początku nowej epoki - ery twórczości zbiorowej ${ }^{79}$. Potwierdzenie zasadności obranego kierunku płynęło również ze strony innych nauk społecznych. Jak zauważył Aleksander Matejko: „Kolektywizm uważany jest przez socjologów za istotną cechę organizacji socjalistycznej" "80.

Kolektywizm uzyskał status zasady uniwersalnej. Miał sprawdzać się we wszystkich dziedzinach życia, w mikroorganizacjach oraz na każdym poziomie makroorganizacji ${ }^{81}$. Wiązano tę ideę $\mathrm{z}$ próbą praktycznego zastosowania koncepcji Marksa, zgodnie z którą państwo zostanie całkowicie podporządkowane

75 B. Suchodolski, Wychowanie dla przyszłości, Warszawa 1959, s. 178.

76 S. Kowalewska, Psychospołeczne..., s. 48-49; C. Miłosz, op. cit., s. 181-182; H. Król, Istota polityki kadrowej, „Przegląd Organizacji” 1977, nr 1, s. 1-5.

77 K. Piłejko, Model..., s. 108-109, 115; E. Lipiński, Teoria ekonomii. Aktualne zagadnienia gospodarcze, Warszawa 1961, s. 121; J. Zieleniewski, Organizacja..., s. 352; S. Strumilin, Problemy socjalizmu i komunizmu w ZSRR, przeł. Z. Dąbrowa et al., Warszawa 1962, s. 250.

78 W.I. Lenin, Dzieła wybrane, t. 1, Warszawa 1949, s. 597.

79 T. Kotarbiński, Traktat o dobrej robocie, Wrocław 1973, s. 314.

80 A. Matejko, Socjologia zakładu pracy, Warszawa 1961, s. 259.

81 K. Piłejko, Model..., s. 119. 
społeczeństwu przed ostatecznym obumarciem ${ }^{82}$. Zwierzchnia pozycja ludu pracującego zdaniem reprezentantów nurtu znalazła praktyczne odbicie w systemie rad, stanowiących emanację idei kolektywizmu na płaszczyźnie władczej. Wpisała się przy okazji w proces decentralizacji władzy. Rozumowanie to świadczy o uznaniu wyższości demokracji bezpośredniej nad pośrednią zgodnie z filozofią polityczną Jean-Jacques'a Rousseau. Nawiązywało również do deklaracji Lenina, który nazywał aktywny udział mas w sprawowaniu władzy „najwyższą formą demokratycznej zasady organizacji” ${ }^{83}$. Instytucjonalizacja idei kolektywizmu przybierała postać rad narodowych, którym obok roli ośrodka władzy na poszczególnych poziomach struktury państwa przypisywano funkcję korygującą i kontrolną — miały one zapobiegać biurokratyzacji oraz kumulacji nadmiaru władzy w ręku jednostek ${ }^{84}$.

Dialektyczna sprzeczność między dążeniami jednostek, zmierzających do maksymalizacji swobody, oraz kolektywu, którego istota polegała na współdziałaniu dla dobra wspólnego, miała ostatecznie prowadzić do uzgodnienia indywidualnych preferencji. Jedność przeciwieństw skutkowała syntezą przenoszącą stosunki międzyludzkie na wyższy poziom rozwoju ${ }^{85}$. W społeczeństwie socjalistycznym sprawy prywatne jednostek zaangażowanych w realizację celów wspólnych stawały się automatycznie sprawami ogólnospołecznymi, za które odpowiadało państwo. Stąd według teoretyków organizacji socjalistycznej wynikała tak wielka dbałość ,władzy ludowej” o załatwianie spraw indywidualnych. Aktywność państwa na tym polu pociągała także z sobą konieczność dostosowania aparatu administracyjnego państwa socjalistycznego do nowych wyzwań oraz zwiększającego się katalogu realizowanych zadañ ${ }^{86}$.

\section{Cechy organizacji socjalistycznej w ujęciu dynamicznym}

Część cech przypisanych organizacji socjalistycznej wiązała się z preferowanymi metodami działania. Pośród nich znalazły się: 1) centralizm demokratyczny; 2) „uplanowienie” i preparacja działań; 3) współdziałanie; 4) model kierownictwa oraz 5) kontrola. Fundamentalne znaczenie w ustroju socjalistycznym miała pierwsza z wymienionych. Jak podkreślał Piłejko:

Zasada centralizmu demokratycznego stanowi połączenie centralnego kierownictwa z demokratycznymi metodami jego sprawowania. Zasada ta jest połączeniem dwu tendencji, które stanowią nierozerwalną dialektyczną jedność jako metoda kierowania i zarządzania w orga-

\footnotetext{
82 K. Marks, F. Engels, Dzieła wybrane, t. 2, Warszawa 1949, s. 22.

83 W.I. Lenin, Dzieta, t. 27, s. 14.

84 J. Starościak, Elementy nauki administracji, Warszawa 1964, s. 103-115.

85 K. Piłejko, Model..., s. 122-123.

86 S. Kowalewski, Szkice z zakresu nauki o administrowaniu, Warszawa 1965, s. 67 n.
} 
nizacji socjalistycznej, wynikająca z ogólnych założeń ustrojowych. Demokratyzm jako niezbędne uzupełnienie centralizmu ma zapobiegać przerostom administracyjnego zarządzania ${ }^{87}$.

Z kolei Kieżun przy okazji krytycznej oceny koncepcji „rewolucji menadżerów" Jamesa Burnhama ${ }^{88}$ dowodził, że połączenie antynomii centralizmu i demokratyzacji prowadzi do uzyskania równowagi między spójnością decyzji podejmowanych przez centralny ośrodek decyzyjny a swobodą preparacji i realizacji działań wynikających ze specyfiki demokratyzmu, uwzględniającego uczestnictwo społeczeństwa w procesie sprawowania władzy ${ }^{89}$.

Legitymizacji centralizmu demokratycznego oraz eliminacji wątpliwości dotyczących racjonalności tego rozwiązania służyło odwoływanie się do autorytetu Lenina. Do korzyści płynących z tego rozwiązania wódz rewolucji zaliczył: 1) zbliżenie mas do aparatu rządzenia ${ }^{90}$;2) możliwość dyskutowania i współodpowiedzialność ${ }^{91}$; 3) budowanie nowych więzi społecznych i wzrost dyscypliny $^{92}$; 4) rozwój inicjatyw lokalnych ${ }^{93}$; 5) integrację celów partykularnych i społecznych ${ }^{94}$; 6) naukowość organizacji pracy ${ }^{95}$. Lenin deklarował, że władza radziecka powinna czerpać siłę z zaufania i pozytywnego stosunku do niej ludu pracującego ${ }^{96}$. Dzięki centralizmowi demokratycznemu realizowany miał być proces prorokowanej przez Marksa dyfuzji państwa i społeczeństwa oraz stopniowego obumierania tego pierwszego.

Przy okazji eksponowania roli wspomnianej zasady uwzględniono fakt, że postępujący proces rozwoju dialektycznego nie zachodzi bez napięć i konfliktów. Dzięki powiązaniu w jedność antynomii centralizmu i demokratyzmu niwelowane miały być negatywne skutki uboczne postępu ${ }^{97}$. Konsekwencją godzenia sprzecznych tendencji miała być natomiast synteza korzyści, polegająca na zwiększeniu poziomu decentralizacji $\mathrm{w}$ zakresie załatwiania spraw bieżących oraz centralizacji w kwestiach ogólnych ${ }^{98}$. O znaczeniu tej idei dla ówczesnego systemu świadczy podniesienie jej do rangi zasady konstytucyjnej (art. 7 Konstytucji PRL).

\footnotetext{
87 K. Piłejko, Model..., s. 127.

88 Zob. J. Burnham, Rewolucja manadżerska, przeł. J. Horzelski, Paryż 1958, s. 92 n., 217 n.

89 W. Kieżun, op. cit., s. 47, 165.

90 W.I. Lenin, Dzieła, t. 27, s. 209-210, 150; t. 30, s. 333.

91 W.I. Lenin, Dzieła, t. 27, s. 213, 277; t. 30, s. 214.

92 W.I. Lenin, Dzieła, t. 27, s. 307; t. 29, s. $168,367,417$; t. 30, s. 524, 531

93 W.I. Lenin, Dzieła, t. 27, s. 209-210.

94 W.I. Lenin, Dzieta, t. 26, s. 417; t. 28, s. 419; t. 30, s. 132.

95 W.I. Lenin, Dzieła, t. 27, s. 205, 309, 320; t. 30, s. 243.

96 W.I. Lenin, Dzieta, t. 29, s. 246.

97 Z. Rybicki, Zarzadzanie gospodarka narodowa w PRL, Warszawa 1963, s. 58.

98 J. Wiatr, Szkice o materializmie historycznym i socjologii, Warszawa 1962, s. 195; L. Habuda, Prakseologiczne aspekty realizacji zasady centralizmu demokratycznego w administracji państwowej, [w:] Socjalistyczna teoria..., s. 164 n.
} 
Centralizm demokratyczny reprezentuje nową metodę rządzenia i zarządzania odpowiadającego tym bardziej ustrojowi socjalistycznemu, że jednocześnie zwiększyły się i powstały nowe funkcje makroorganizacji, mające odbicie w mikroorganizacji ${ }^{99}$.

Kolejnym ważnym elementem modelu organizacji socjalistycznej była planowość, uznawana za formę preparacji działań. Rola, jaką jej przypisywano, wiązała się z poszukiwaniem sposobu kontrolowania i racjonalizowania procesu budowy nowego ustroju przez uprawianie uporządkowanego namysłu nad podejmowanymi działaniami. Jak podkreślano: „Preparacja jest odwzorowaniem myślowym przyszłej sytuacji, jaka powstanie na dalszych etapach realizacji”100. Zdaniem klasyków marksizmu przemyślane działania na wszystkich poziomach państwa stanowiły cechę odróżniającą socjalistyczny system społeczno-gospodarczy od żywiołowego i nieprzewidywalnego modelu kapitalistycznego. Engels podkreślał, że planowość pozwoliła nie tylko wynieść gatunek ludzki ponad świat zwierzęcy, lecz także potwierdziła wyższość socjalizmu nad innymi modelami ustrojowymi ${ }^{101}$.

Planowość pojmowano szerzej aniżeli planowanie. „Planowanie czyni zadość założeniom marksistowskim tylko wówczas, gdy realizuje całkowicie zasadę planowości, a tym samym zasadę racjonalności społeczno-gospodarczej"102. Zdaniem teoretyków planowość leżała u podstaw nowoczesnej cywilizacji XX wieku. Najwyższy poziom jej rozwoju osiągnęły kraje socjalistyczne. Sięgająca oświecenia wiara w możliwości ludzkiego rozumu powodowała, że racjonalny namysł nad działaniem przyszłym zyskiwał w rozwoju teorii organizacji socjalistycznej walor dyrektywy o zastosowaniu uniwersalnym. Dotyczył zarówno makro-, jak i mikroorganizacji, a wynikał z przekonania o korzyściach świadomego kształtowania przyszłej rzeczywistości ${ }^{103}$.

Wśród elementów składających się na preparację działań wymieniano: 1) zbieranie potrzebnych informacji; 2) ,upośrednienie” akcji; 3) instrumentalizację zaprojektowanych metod pracy. Natomiast do cech charakteryzujących planowanie socjalistyczne dodawano ponadto: 1) powszechność; 2) całościowość na płaszczyźnie makroorganizacji; 3) kompleksowość; 4) ciągłość. Ten rodzaj planowania został określony w uchwale IV Zjazdu Komitetu Centralnego PZPR (15-20 czerwca 1964 roku) jako „planowanie kroczące" ${ }^{104}$.

99 K. Piłejko, Model..., s. 129

100 Ibidem, s. 148; M. Lissowska, Nowe ujęcie zagadnienia organizacji gospodarki narodowej, „Przegląd Organizacji” 1976, nr 1, s. 38-39.

101 F. Engels, Wstęp do „Dialektyki przyrody”, [w:] K. Marks, F. Engels, Dzieła wybrane, t. 2, s. 63-64.

102 K. Piłejko, Model..., s. 144.

103 B. Minc, Ekonomia polityczna socjalizmu, Warszawa 1961, s. 137.

104 K. Piłejko, Model..., s. 156-157; A. Pyszkowski, Planowanie makroregionalne a plan centralny, „Przegląd Organizacji” 1978, nr 6, s. 241. 
Eksponując znaczenie planowania, za błędne jego pojmowanie uznano próby skrupulatnego rejestrowania wszystkich faktów i informacji, co wiązało się z piętnowaniem jednej z głównych wad systemu — biurokratyzacji. „Granica sprawozdawczości i planowania rozpoczyna się tam, gdzie jedno i drugie w niczym nie dopomaga lub nawet przeszkadza w realizacji zadań" 105 . W planowości liczyła się zatem racjonalność i sprawność oceniana w wymiarze teleologicznym. Wszystko, co wykraczało poza rozsądne granice, należało odrzucać jako niepotrzebne i szkodliwe. Według odwołującego się do dyrektyw prakseologicznych Piłejki pośród walorów dobrego planu należało wymienić: 1) celowość; 2) wykonalność; 3) zgodność wewnętrzną; 4) operatywność; 5) elastyczność; 6) szczegółowość należycie ograniczoną; 7) długodystansowość; 8) terminowość; 9) kompletność oraz 10) racjonalność 106 .

Idea planowości wpisywała się $\mathrm{w}$ ambitne założenie świadomego kierowania postępem. Jego warunkiem koniecznym były innowacje, definiowane jako wartości kulturowe uznawane w danym miejscu i czasie jako nowość. Wskazywano, iż każda zmiana wymaga od ludzi umiejętności, energii i motywacji, które łącznie pozwalały zaadaptować się do nowych warunków. Na tym polu kluczową rolę miało odgrywać państwo socjalistyczne, a w szczególności PZPR występująca jako inicjator planowego postępu ${ }^{107}$. Dla przykładu, według wytycznych na VII Zjazd PZPR: „Kierownictwo PZPR postawiło przed narodem atrakcyjny i ambitny program zbudowania w ciągu najbliższych lat drugiej, bogatszej, piękniejszej i sprawiedliwszej Polski Ludowej" 108 . W ocenie reprezentantów nurtu organizacji socjalistycznej szczególne znaczenie dla procesu rozwoju miał postęp techniczny, w tym komputeryzacja ${ }^{109}$, traktowany jako ważny czynnik postępu przebiegającego zgodnie z zasadami dialektyki ${ }^{110}$.

Teoretycy organizacji socjalistycznej doby PRL eksponowali współdziałanie jako właściwy kierunek rozwoju zarówno jednostek, jak i stosunków społecznych, uznając wspomnianą ideę za szczególnie sprzyjającą budownictwu socjalistycznemu. Kooperacja łączyła się z innymi założeniami ustrojowymi. Nacjonalizacja środków produkcji, własność uspołeczniona oraz charakter celów stawianych przed państwem socjalistycznym wymagały wszak współpracy. Pomimo powszechności znaczenia współpraca mogła zyskać swoją pełnię dopiero w ustroju socjalistycznym, w którym miała odgrywać rolę fundamentu porządku społecznego na

105 K. Piłejko, Model..., s. 158.

106 Ibidem, s. 159-160.

107 M. Holstein-Beck, op. cit., s. 107-108.

108 Wytyczne na VII Zjazd PZPR, Warszawa 1975, s. 8-9.

109 W. Radzikowski, Najnowsze osiagnięcia radzieckiej nauki i praktyki w zakresie organizacji i zarzadzania (na przykładzie ilościowych technik zarzadzania), [w:] Wptyw Wielkiej Socjalistycznej Rewolucji Październikowej..., s. 29-36; J. Kurnal, Polski wkład..., s. 81-82.

110 K. Hajduk-Popławska, Wplyw techniki na zarzadzanie, [w:] Socjalistyczna teoria..., s. $254 \mathrm{n}$. 
wszystkich jego poziomach ${ }^{111}$. Kolektywność oraz zespołowość miały spełniać szczególną funkcję w procesie socjalizacji człowieka, wyrobienia w nim odpowiedzialności i poczucia własnej wartości. W konsekwencji przypisanego znaczenia problematyce tej nadawano rangę dyrektyw o randze uniwersalnej ${ }^{112}$.

Podobnie jak miało to miejsce $\mathrm{w}$ odniesieniu do innych zasad organizacji socjalistycznej, w wypadku współdziałania odwoływano się do autorytetu klasyków. Wskazywano, że Marks poświęcił teorii kooperacji pozytywnej obszerny fragment Kapitału, wskazując na jej znaczenie jako źródła „specyficznej siły produkcyjnej"113. Chociaż Marks koncentrował się na procesach produkcyjnych, Piłejko uznał za uprawnioną ekstrapolację jego rozumowania na inne obszary działań zespołowych. Autor ten nawiązywał także do stanowiska Lenina, podkreślającego znaczenie kooperacji dla organizacji socjalistycznej, w szczególności w jej wymiarze politycznym i administracyjnym. We współpracy szerokich mas miała tkwić siła postępu i demokratyzacji ${ }^{114}$.

Istotne znaczenie przypisywano sposobowi kierowania. Charakterystycznym rysem modelu organizacji socjalistycznej był, wymieniony wcześniej, demokratyczny styl kierowania. Teoretycy nurtu zdawali sobie sprawę z rozbieżności teorii i praktyki. Formułując pogląd o zasięgu uniwersalnym, asekurowali się stwierdzeniem, iż postulowany model nie upowszechnił się jeszcze dostatecznie szeroko. Przeszkód w jego pełnym wdrażaniu doszukiwano się w gwałtownym procesie industrializacji i urbanizacji, napiętych planach produkcyjnych, nieznajomości najnowszych osiągnięć teorii organizacji wśród kadry zarządzającej oraz kapitalistycznych nawykach kierowników. Podkreślano, że w socjalistycznym systemie społeczno-gospodarczym kierownik powinien odgrywać rolę usługową wobec podległych mu pracowników ${ }^{115}$.

Legitymizacji idei demokratycznego modelu kierowania służyły poglądy Lenina. Autorzy powoływali się na interpretację poglądów wodza rewolucji zawartą w referacie Breżniewa wygłoszonym podczas XXV Zjazdu KPZR (1976 rok). Pośród immanentnych cech Leninowskiej wizji kierowania znalazły się: 1) walor naukowości; 2) oparcie na racjonalnych przesłankach; 3) eliminacja subiektywizmu; 4) synteza teorii i doświadczeń praktycznych; 5) oparcie na doświadczeniach uogólnionych oraz 6) zaangażowanie mas ludowych w procesy zarządzania ${ }^{116}$.

111 A. Matejko, op. cit., s. 39; S. Kowalewska, op. cit., s. 226; J. Wacławek, Kształtowanie się socjalistycznych stosunków międzyludzkich $w$ zakładzie przemystowym, Warszawa 1965, s. 62; K. Piłejko, Model..., s. 161.

112 B. Biegeleisen-Żelazowski, Wiedza o pracy ludzkiej, Warszawa 1959, s. 82; K. Piłejko, Model..., s. 190.

113 K. Marks, Kapitat, t. 1, Warszawa 1951, s. 350, 354.

114 K. Piłejko, Model..., s. 164-165, 166.

115 S. Kowalewski, Przełożony-podwładny, Warszawa 1967, s. 299; W. Kieżun, op. cit., s. 156; S. Kwiatkowski, Socjalistyczny styl kierowania (przyczynek do socjalistycznej teorii organizacji), „Przegląd Organizacji” 1977, nr 3, s. 110-114.

116 S. Kowalewski, Wykorzystanie dorobku..., s. 15-16. 
Polscy teoretycy nurtu traktowali typ kierownictwa demokratycznego jako integralny element nowego ustroju. Kierownictwo rozkazodawcze, przypisywane formacji kapitalistycznej, oceniono jako mało efektywne. Stosownie do postulatu humanizacji stosunków międzyludzkich eksponowano służebną rolę kadry zarządzającej. Kierownicy mieli przede wszystkim koordynować poszczególne funkcje w organizacji. Kolektywizację działań porównywano do łączenia wirtuozów w zespół, na czele którego stał dyrygent. Temu stanowisku towarzyszyło przekonanie o obowiązku zachowania szacunku wobec ludzkiej pracy, niezależnie od miejsca zajmowanego przez jednostkę w zespole ${ }^{117}$.

Rozumując dialektycznie, ideę demokratycznego kierownictwa próbowano łączyć z zasadą jednoosobowego kierownictwa oraz jednoosobowej odpowiedzialności. Stanisław Kowalewski przytoczył wypowiedź Lenina ${ }^{118}$, któremu przypisywał sukces pogodzenia zasady demokratyzacji z postulatami nauki organizacji. Pogląd wodza rewolucji przybrał formę krótkiej dyrektywy: „Kolegialność przy podejmowaniu decyzji — jednoosobowość i jednoosobowa odpowiedzialność przy wprowadzaniu ich w życie" 119 .

Niezależnie od chwytliwego hasła demokratyzacji i udziału społeczeństwa w procesie kierowania systemem społeczno-gospodarczym teoretycy organizacji socjalistycznej, mniej lub bardziej świadomie nawiązując do kategorii cybernetycznych, eksponowali rolę podsystemu sterującego ${ }^{120}$, którego zadaniem było nadawanie kierunku działań całemu układowi. Wspomnianą funkcję określano mianem działalności inicjatorsko-kreatywnej. W ten sposób legitymizowano kierowniczą rolę PZPR, której podporządkowano konstytucyjne organy państwa, sankcjonując jednocześnie na polu teoretycznym praktykę łamania porządku konstytucyjnego PRL. Zgodnie z akceptowanym modelem makroorganizacji:

Decyzje podejmowane w tym układzie przybierają postać nakazów, dyrektyw (o różnym stopniu stanowczości), jak również zaleceń. Plan gospodarki narodowej jest zatwierdzany przez Sejm i nosi prawny charakter ustawy. Uchwały Zjazdów PZPR mają charakter dyrektyw określających kierunki rozwoju społeczno-ekonomicznym kraju (wiązano to ze szczególną rolą partii marksistowsko-leninowskiej w okresie dyktatury proletariatu) $[\ldots]^{121}$.

W okresie budowy społeczeństwa socjalistycznego organizacyjna działalność partii miała koncentrować się na kilku płaszczyznach: 1) formułowaniu programu działania państwa; 2) oddziaływaniu motywacyjnym; 3) kontroli wykonania przyjętych planów; 4) bieżącej analizie problemów społecznych i rozwiązywaniu

117 J. Lutosławski, Człowiek w przedsiębiorstwie przemysłowym, Warszawa 1960, s. 111; A. Skowroński, Nowoczesne metody organizacji przedsiębiorstw, Poznań 1965, s. 40, 98-100, 111; T. Kotarbiński, Traktat..., s. 237-238; J. Zych, Koncepcja funkcji kierowniczych i nie kierowniczych w instytucji socjalistycznej, [w:] Socjalistyczna teoria..., s. 194 n.

118 W.I. Lenin, Dzieła, t. 30, s. 244-245.

119 S. Kowalewski, Wykorzystanie dorobku..., s. 20; zob. też A. Ehrlich, op. cit., s. 88-90.

120 Zob. F. Studnicki, Cybernetyka i prawo, Warszawa 1969, s. 56; A. Malinowski, Wstęp do badań cybernetycznych w prawoznawstwie, Warszawa 1977, s. 136.

121 W. Kieżun, op. cit., s. 144.

Studia nad Autorytaryzmem i Totalitaryzmem 41, nr 4, 2019

(C) for this edition by CNS 
konfliktów wpisanych w dialektyczny proces jego rozwoju; 5) wysuwaniu członków partii na kierownicze stanowiska; 6) ocenie ich działań według kryteriów wyznaczonych przez partię ${ }^{122}$.

W nurcie nauki organizacji inspirowanej leninizmem rozróżniano, znajdujące na przeciwległych biegunach skali, dwa style kierowania: autokratyczny i demokratyczny. Pomiędzy nimi znajdował się wachlarz rozwiązań pośrednich. Im styl kierowania bliższy był modelowi demokratycznemu, tym bardziej odpowiadał teoretycznym założeniom socjalistycznej nauki organizacji. Deklarowano, że kierowanie w socjalizmie miało zmierzać do realizacji celów społecznie wartościowych. Za jedną z instytucjonalnych gwarancji spełnienia tego warunku uznawano zaangażowanie załóg pracowniczych w procesy decyzyjne ${ }^{123}$.

W modelu organizacji socjalistycznej istotne znaczenie przypisywano także kontroli. W świetle refleksji inspirowanej poglądami Stalina ${ }^{124}$ potrzeba ta wynikała z konieczności ochrony interesu społecznego. Poprzez wyzwalanie konfliktów nieantagonistycznych stanowiła narzędzie zorganizowanej krytyki oraz stymulowała do doskonalenia metod działania. Obok tradycyjnej zinstytucjonalizowanej kontroli prowadzonej przez organy polityczne i państwowe deklarowano potrzebę prowadzenia działań nadzorczych przez reprezentantów ludu pracującego. Sprzyjał temu przyjęty model kierownictwa demokratycznego, który wobec zmienności przyjmowanych ról prowadził do zacierania granic między przełożonymi i podwładnymi, kontrolującymi i kontrolowanymi ${ }^{125}$.

\section{Kilka wniosków}

Próba sformułowania wniosków dotyczących koncepcji organizacji socjalistycznej tworzonej w latach 1956-1981 natrafia na poważną komplikację. Dyscyplina należy bowiem do kategorii nauk praktycznych, których wartość poznawcza oceniana jest przez pryzmat przydatności jej wyników w działaniu. Tymczasem trudno o bardziej jaskrawy przykład rozbieżności między przedstawioną refleksją teoretyczną a rzeczywistością, aniżeli miało to miejsce w Polsce Ludowej.

Przy obserwacji wspomnianej rozbieżności nasuwa się skojarzenie z podstawową cechą totalitaryzmu komunistycznego, którą George Orwell określił jako „dwójmyślenie"126. Mniej literackiego, ale za to bardziej dosadnego określenia użył, powołując się na Leszka Kołakowskiego, Adam Lityński, stwierdzając, że

komunizm był najbardziej zakłamanym systemem w dziejach ludzkości. Nigdy i nigdzie nie było takiej rozbieżności między głoszonymi ideami, hasłami, oświadczeniami, prawem na pa-

\footnotetext{
122 Ibidem, s. 161-162.

123 S. Kowalewski, Wybrane elementy..., s. 30-32, 39.

124 J. Stalin, Dzieła, t. 4, Warszawa 1951, s. 377.

125 W. Kieżun, op. cit., s. 43-44; por. A. Ehrlich, op. cit., s. 90-93.

126 G. Orwell, Rok 1984, przeł. T. Mirkowicz, Warszawa 2015, s. 35-36.
} 
pierze a rzeczywistością — z reguły wręcz drastycznie odmienną. „Uniwersalne kłamstwo, totalne kłamstwo" (L. Kołakowski) to jedna z ważnych cech systemu ${ }^{127}$.

Odnosząc wspomnianą cechę totalitaryzmu komunistycznego do wzorowanej na nim rzeczywistości autorytarnego modelu sprawowania władzy w PRL, ocenę koncepcji organizacji socjalistycznej należałoby oddzielić od praktyki organizatorskiej, z którą ta pierwsza zazwyczaj nie miała wiele wspólnego.

W pierwszej kolejności nasuwa się wniosek o znaczącym nasyceniu nauk o organizacji i zarządzaniu w Polsce doby „realnego socjalizmu” wątkami ideologicznymi ${ }^{128}$. Jako skrajną postać tego zjawiska należy wskazać koncepcję organizacji socjalistycznej. Szczególnie widoczne są tu próby uzgodnienia „na siłę" przedmiotu dyscypliny z założeniami marksizmu w sposób pozwalający zbudować spójny, hierarchiczny system dyrektyw praktycznych. Nauki o organizacji wedle założeń koncepcji organizacji socjalistycznej powinny stać się jednym z narzędzi pozwalających skonkretyzować i uszczegółowić mgliste i często sprzeczne postulaty ideologiczne ${ }^{129}$, dzięki czemu uczestniczyłyby w praktyce budownictwa socjalistycznego. Przez implementowanie licznych założeń oficjalnej ideologii miały wpisywać się w wizję ustrojową Polski Ludowej.

Analizując osiągnięcia teoretyków zajmujących się koncepcją organizacji socjalistycznej, nie można pominąć ich prób „zracjonalizowania irracjonalnego", polegających na wysiłkach zmierzających do przeniesienia abstrakcyjnych założeń ideologicznych na grunt nauk praktycznych. Należy przyznać, że w niektórych obszarach to się udało, choć nie oznacza to, że nie było również słabszych fragmentów rozważań. Jako przykład porażki można wskazać wyraźne uprzedmiotowienie, wbrew deklaracjom, człowieka oraz bezkrytyczne przejęcie rozumowania właściwego inżynierii społecznej, zakładającego woluntarystyczne przekonanie o nieograniczonych możliwościach formowania świata ludzkiego zgodnie z wolą polityczną. Na skutek poddawania się tego rodzaju dogmatyzmowi podejmowano naiwne próby algorytmizacji procesów społecznych oraz wyrażano przekonanie, że racjonalny namysł nad zbiorowymi formami egzystencji grupowej, wsparty materializmem dialektycznym i historycznym, pozwoli rozwiązać wszystkie praktyczne problemy oraz umożliwi zbudowanie idealnego państwa przyszłości. Stąd już tylko krok do myślenia utopijnego, nielicującego $\mathrm{z}$ aspiracjami formułowania naukowych wskazówek sprawnego działania.

$\mathrm{Z}$ wpisującymi się w totalitarną tendencję do uniformizacji jednostek próbami algorytmizowania opisywanej rzeczywistości społecznej wiązała się charakterystyczna dla prezentowanego nurtu szczególnego rodzaju odhumanizowana

127 A. Lityński, Prawo Rosji i ZSRR 1917-1991, czyli historia wszechzwiąkowego komunistycznego prawa (bolszewików). Krótki kurs, Warszawa 2017, s. 17.

128 Jako przykłady tego zjawiska należy wskazać liczne odwołania na łamach „Przeglądu Organizacji”, będącego głównym organem środowiska badawczego zainteresowanego naukową organizacją i zarządzaniem.

129 L. Kołakowski, op. cit., s. 883, 1210. 
terminologia, sztuczna „nowomowa” wzorowana na naukach technicznych. Dlatego na pierwszy rzut oka prowadzone na tej płaszczyźnie rozważania o organizacji i funkcjonowaniu państwa nie wpisują się w konwencję tradycyjnego kanonu myślenia politycznego. Przekroczenie bariery wynikającej ze specyfiki kodu komunikacyjnego dyscypliny pozwala jednak właściwie odczytać rzeczywisty cel analizowanych wypowiedzi - był nim namysł nad państwem, społeczeństwem i polityką. Co więcej, kiedy już zaakceptujemy charakterystyczną konwencję wypowiedzi, widoczne stają się wyraźne związki między wspomnianą formą stosowaną w naukach o organizacji doby PRL oraz specyficznym stylem komunikacji będącym immanentną cechą marksizmu-leninizmu.

Trudno jednoznacznie rozstrzygnąć, w jakim stopniu ówcześni twórcy socjalistycznej teorii organizacji rzeczywiście akceptowali założenia obowiązującej ideologii, a na ile był to jedynie intelektualny „haracz” płacony przez wszystkich reprezentantów nauk społecznych, polegający na obowiązkowym odwołaniu się w pracy naukowej do autorytetu klasyków marksizmu. W wielu przypadkach dostrzegalna jest wiara w zasadność prowadzenia tego rodzaju refleksji intelektualnej. Wydaje się, iż kwestię tę należy rozpatrywać w sposób zindywidualizowany. Nieco światła na wspomniane zagadnienie rzuca ogólna tendencja, jaka zarysowała się w publikacjach poświęconych problematyce organizacyjnej w latach 1944-1989. O ile w okresie stalinizmu jakiekolwiek odstępstwo od ortodoksji marksistowskiej było niedopuszczalne, o tyle po „odwilży” 1956 roku doszło do stopniowego poluzowania ideologicznego gorsetu. W konsekwencji w latach 1956-1981, mimo wciąż znaczącej pozycji socjalistycznej nauki organizacji, stopniowo zaczęły się pojawiać — coraz liczniejsze — odwołania do osiągnięć nauki obozu kapitalistycznego. Wskutek postępujących przemian szczególnie w trakcie zachodzącego w latach osiemdziesiątych XX wieku gwałtownego procesu erozji systemu PRL korzystano już obficie z dorobku nauki zachodniej.

Prowadząc badania nad nurtem organizacji socjalistycznej w polskich naukach organizacji i zarządzania, należy jednak pamiętać, że był to jedyne fragment bardzo szerokiego obszaru refleksji naukowej. Niezależnie od nacisków ideologicznych i rzeczywistego wpływu marksizmu-leninizmu na sferę naukową w PRL poza obszarem bezpośredniego oddziaływania powstawało wiele wartościowych projektów naukowych, których kontynuacja była prowadzona po 1989 roku, pośrednio przyczyniając się do tempa przemian polityczno-prawnych i społeczno-gospodarczych. Dorobek ten stał się elementem podwalin rzeczywistości III Rzeczypospolitej, w tym licznych dyscyplin naukowych, takich jak nauka administracji i zarządzanie publiczne.

Mimo że celem artykułu było stworzenie szkicu założeń tylko jednego z nurtów refleksji naukowej prowadzonej w obszarze nauk o organizacji i zarządzaniu w dobie PRL, przeprowadzona analiza pozwoliła na identyfikację interesującego obszaru eksploracji naukowej. Potwierdza bowiem, iż podjęcie systematycznych badań na gruncie dorobku nauk praktycznych doby PRL pozwoliłoby na pełniejszą 
analizę i lepsze zrozumienie rzeczywistości lat 1944-1989. W szczególności badania te mogłyby rzucić nowe światło na proces detotalizacji systemu politycznego, który pomimo obiektywnej niemożliwości dążył do „urzeczywistnienia komunistycznej utopii" ${ }^{130}$. Jego twórcy mieli początkowo aspiracje do zawładnięcia nie tylko ciałami, ale i duszami Polaków, z czasem zadowalając się już tylko monopolem władzy politycznej, aby ostatecznie zostać zmuszonymi oddać ją opozycji. Reprezentatywnym i jednocześnie ciekawym polem rekonstrukcji przebiegu przemian w okresie powojennym może być proces uniezależniania się polskiej nauki organizacji i zarządzania od wpływów ideologii marksistowsko-leninowskiej.

\section{Bibliografia}

Adamiecki K., O nauce organizacji. Wybór pism, Warszawa 1970.

Aranowski A., Koncepcja systemu ekonomicznego — podejście organizacyjne, „Przegląd Organizacji” 1976, nr 1.

Arystoteles, Polityka, przeł. L. Piotrowicz, Warszawa 1964.

Bertalanffy L., Ogólna teoria systemów. Podstawy, rozwój, zastosowania, przeł. E. Woydyłło-Woźniak, Warszawa 1984.

Biegeleisen-Żelazowski B., Wiedza o pracy ludzkiej, Warszawa 1959.

Burnham J., Rewolucja manadżerska, przeł. J. Horzelski, Paryż 1958.

Czapów C., Socjotechnika w zaktadzie pracy, Warszawa 1975.

Drecin J., Socjalistyczna polityka gospodarcza a zarządzanie przedsiębiorstwami, „Przegląd Organizacji" 1976, nr 3.

Drozdowicz J., Znaczenie wielkiej socjalistycznej rewolucji październikowej dla spółdzielczości w Polsce, [w:] Wpływ Wielkiej Socjalistycznej Rewolucji Październikowej i nauki radzieckiej na rozwój organizacji i zarzadzania w PRL. 60-lecie Wielkiej Socjalistycznej Rewolucji Październikowej. Ogólnokrajowa konferencja naukowa, Warszawa 1977.

Ehrlich A., Wpływ wielkiej socjalistycznej rewolucji październikowej i nauki radzieckiej na rozwój organizacji i zarzadzania w PRL, [w:] Wptyw Wielkiej Socjalistycznej Rewolucji Październikowej i nauki radzieckiej na rozwój organizacji i zarządzania w PRL. 60-lecie Wielkiej Socjalistycznej Rewolucji Październikowej. Ogólnokrajowa konferencja naukowa, Warszawa 1977.

Engels F., Wstęp do „Dialektyki przyrody”, [w:] K. Marks, F. Engels, Dzieła wybrane, t. 2, Warszawa 1949.

Filozofia marksistowska, red. J. Grudzień, H. Jankowski, T.M. Jaroszewski, W. Wesołowski, wyd. 5, Warszawa 1978.

Głodziński E., „Przeglad organizacji” - wczoraj i dziś. Rola czasopisma w rozwoju nauk o zarzadzaniu. Cz. 1, „Przegląd Organizacji” 2016, nr 3.

Gogłoza W., Księski K., Historia myśli organizatorskiej. Zarys wykładu, Warszawa 2013.

Habuda L., Prakseologiczne aspekty realizacji zasady centralizmu demokratycznego w administracji państwowej, [w:] Socjalistyczna teoria organizacji. Koncepcje - kierunki, red. S. Kowalewski, Warszawa 1977.

Hajduk-Popławska K., Wpływ techniki na zarzadzanie, [w:] Socjalistyczna teoria organizacji. Koncepcje — kierunki, red. S. Kowalewski, Warszawa 1977.

Holstein-Beck M., Problemy kierowania postepem, [w:] Socjalistyczna teoria organizacji. Koncepcje - kierunki, red. S. Kowalewski, Warszawa 1977.

130 A. Walicki, Dwa spojrzenia..., s. 291-292.

Studia nad Autorytaryzmem i Totalitaryzmem 41, nr 4, 2019

(C) for this edition by CNS 
Idee organizatorskie W.I. Lenina, „Prakseologia” 1970, nr 36. Lenin a teoria i praktyka organizacji.

Kania R., Marksizm-leninizm a cybernetyka prawa w PRL. Zarys problematyki, „Miscellanea Historico-Iuridica" $16,2017, \mathrm{nr} 1$.

Kania R., Rozvitokpravovoï kibernetiki u Pol'sì v HH-mustoriččì, „Ìnformaciâì Pravo Naukovij Fahovij Žurnal" 2018, nr 1.

Kieżun W., Elementy socjalistycznej nauki o organizacji i zarządzaniu, Warszawa 1978.

Kołakowski L., Główne nurty marksizmu. Powstanie — rozwój — rozkład, Londyn 1988.

Konstytucja Polskiej Rzeczypospolitej Ludowej z dnia 22 lipca 1952 roku (Dz.U. Nr 33, poz. 232 ze zm.).

Kotarbiński T., Traktat o dobrej robocie, Wrocław 1973.

Kotarbiński T., Wybór pism, t. 1. Myśli o działaniu, Warszawa 1957.

Kowalewska S., Psychospołeczne warunki pracy w przedsiębiorstwie przemystowym. Studium o systemie społecznym socjalistycznego przedsiębiorstwa, Warszawa 1962.

Kowalewski S., O książkach. Podstawy marksistowskiego zarządzania i kierowania, „Przegląd Organizacji” 1978, nr 1.

Kowalewski S., Pojęcie powodzenia instytucji (przyczynek do socjalistycznej teorii organizacji), „Przegląd Organizacji” 1977, nr 1.

Kowalewski S., Przełożony-podwładny, Warszawa 1967.

Kowalewski S., Samorealizacji w świetle światopogladu marksistowskiego (przyczynek do socjalistycznej teorii organizacji), „Przegląd Organizacji” 1976, nr 12.

Kowalewski S., Szkice z zakresu nauki o administrowaniu, Warszawa 1965.

Kowalewski S., Wybrane elementy socjalistycznej teorii organizacji i nauki o administrowaniu, [w:] Socjalistyczna teoria organizacji. Koncepcje — kierunki, red. S. Kowalewski, Warszawa 1977.

Kowalewski S., Wykorzystanie dorobku nauki i praktyki radzieckiej $w$ kształtowaniu organizacji i zarządzania w PRL, [w:] Wpływ Wielkiej Socjalistycznej Rewolucji Październikowej i nauki radzieckiej na rozwój organizacji i zarządzania w PRL. 60-lecie Wielkiej Socjalistycznej Rewolucji Październikowej. Ogólnokrajowa konferencja naukowa, Warszawa 1977.

Kowalewski S., Kuc B.R., Słowo wstępne, [w:] Socjalistyczna teoria organizacji. Koncepcje - kierunki, red. S. Kowalewski, Warszawa 1977.

Król H., Istota polityki kadrowej, „Przegląd Organizacji” 1977, nr 1.

Kuc B.R., Warunki efektywnej samokontroli, [w:] Socjalistyczna teoria organizacji. Koncepcje kierunki, red. S. Kowalewski, Warszawa 1977.

Kurnal J., Polski wkład do rozwoju socjalistycznej nauki i praktyki organizacji i zarzadzania, [w:] Wpływ Wielkiej Socjalistycznej Rewolucji Październikowej i nauki radzieckiej na rozwój organizacji i zarządzania w PRL. 60-lecie Wielkiej Socjalistycznej Rewolucji Październikowej. Ogólnokrajowa konferencja naukowa, Warszawa 1977.

Kurnal J., Przydatność prakseologicznej aparatury pojęciowej dla badań nad organizacja przedsiębiorstw handlowych, [w:] Przydatność prakseologicznej aparatury pojęciowej dla poszczególnych dyscyplin naukowych, red. T. Kotarbiński et al., Wrocław-Warszawa 1964.

Kwiatkowski S., Modele myślenia organizacyjnego, „Przegląd Organizacji” 1976, nr 1.

Kwiatkowski S., Socjalistyczny styl kierowania (przyczynek do socjalistycznej teorii organizacji), „Przegląd Organizacji” 1977, nr 3.

Lange O., Całość i rozwój w świetle cybernetyki, Warszawa 1962.

Lange O., Ekonomia polityczna, t. 1, wyd. 2, Warszawa 1961.

Lenin W.I., Dzieła, , t. 9, 27, 29, 30, Warszawa 1953-1957.

Lenin W.I., Dzieła wybrane, t. 1, Warszawa 1949.

Lenin W.I., Zeszyty filozoficzne, Warszawa 1956.

Lipiński E., Teoria ekonomii. Aktualne zagadnienia gospodarcze, Warszawa 1961.

Lissowska M., Nowe ujęcie zagadnienia organizacji gospodarki narodowej, „Przegląd Organizacji” 1976, nr 1.

Studia nad Autorytaryzmem i Totalitaryzmem 41, nr 4, 2019

(C) for this edition by CNS 
Lityński A., Prawo Rosji i ZSRR 1917-1991, czyli historia wszechzwiązowego komunistycznego prawa (bolszewików). Krótki kurs, wyd. 3, Warszawa 2017.

Lutosławski J., Człowiek w przedsiębiorstwie przemysłowym, Warszawa 1960.

Malinowski A., Wstęp do badań cybernetycznych w prawoznawstwie, Warszawa 1977.

Marks K., Kapitat, t. 1, Warszawa 1951.

Marks K, Engels F., Dzieła, t. 4, Warszawa 1962.

Marks K., Engels F., Dzieła wybrane, t. 1-3, Warszawa 1949.

Martyniak Z., Historia myśli organizatorskiej. Wybitni autorzy z zakresu organizacji i zarzadzania w pierwszej połowie XX w., wyd. 4 uzup., Kraków 2002.

Maslow A.H., Motywacja i osobowość, przeł. J. Radzicki, Warszawa 2013.

Matejko A., Przydatność prakseologicznej aparatury pojęciowej dla teorii systemów społecznych, [w:] Przydatność prakseologicznej aparatury pojęciowej dla poszczególnych dyscyplin naukowych, red. T. Kotarbiński et al., Wrocław-Warszawa 1964.

Matejko A., Socjologia zakładu pracy, Warszawa 1961.

Mazur M., Pojęcie systemu i reguly jego stosowania, „Przegląd Organizacji” 1976, nr 12.

Mielnik M., Metody oceny efektywności działalności wielkich organizacji produkcyjnych, „Przegląd Organizacji” 1977, nr 10.

Miłosz C., Zniewolony umyst, Warszawa 2008.

Minc B., Ekonomia polityczna socjalizmu, Warszawa 1961.

Opałek K., Zakrzewski W., Z zagadnień praworzadności socjalistycznej, Warszawa 1958.

Organizacja społeczeństwa socjalistycznego w Polsce, red. A. Łopatka, Warszawa-Poznań 1968.

Orwell G., Rok 1984, przeł. T. Mirkowicz, Warszawa 2015.

Ossowski S., Ku nowym formom życia społecznego, Warszawa 1966.

Parkinson C.N., Prawo Parkinsona, przeł. J. Kydryński, wyd. 2, Warszawa 1964.

Piłejko K., Dialektyka w organizacji, „Prakseologia” 1970, nr 36.

Piłejko K., Model organizacji w ustroju socjalistycznym, Warszawa 1969.

Podgórecki A., Charakterystyka nauk praktycznych, Warszawa 1962.

Podgórecki A., Patologia działania instytucji, [w:] Socjotechnika. Funkcjonalność i dysfunkcjonalność instytucji, red. A. Podgórecki, Warszawa 1974.

Podgórecki A., Socjologia prawa, Warszawa 1962.

Pszczołowski T., Mała encyklopedia prakseologii i teorii organizacji, Wrocław 1978.

Pyszkowski A., Planowanie makroregionalne a plan centralny, „Przegląd Organizacji” 1978, nr 6.

Rachwalski J., Wpływ wielkiej socjalistycznej rewolucji październikowej i nauki radzieckiej na rozwój organizacji i zarządzania w przemyśle w PRL, [w:] Wpływ Wielkiej Socjalistycznej Rewolucji Październikowej i nauki radzieckiej na rozwój organizacji i zarządzania w PRL. 60-lecie Wielkiej Socjalistycznej Rewolucji Październikowej. Ogólnokrajowa konferencja naukowa, Warszawa 1977.

Radzikowski W., Najnowsze osiagnięcia radzieckiej nauki i praktyki w zakresie organizacji i zarzadzania (na przykładzie ilościowych technik zarzadzania), [w:] Wplyw Wielkiej Socjalistycznej Rewolucji Październikowej i nauki radzieckiej na rozwój organizacji i zarządzania w PRL. 60-lecie Wielkiej Socjalistycznej Rewolucji Październikowej. Ogólnokrajowa konferencja naukowa, Warszawa 1977.

Rybicki Z., Zarządzanie gospodarka narodowa w PRL, Warszawa 1963.

Sadownik H., Cele organizacji gospodarczej, „Przegląd Organizacji” 1976, nr 7.

Sarapata A., Rozwój społeczeństwa socjalistycznego — zakład pracy — kadra kierownicza, „Przegląd Organizacji” 1976, nr 4-5.

Schaff A., Wstęp do teorii marksizmu, Warszawa 1948.

Skowroński A., Nowoczesne metody organizacji przedsiębiorstw, Poznań 1965.

Socjologiczne problemy przedsiębiorstwa przemysłowego, red. A. Sarapata, Warszawa 1965.

Starościak J., Elementy nauki administracji, Warszawa 1964.

Studia nad Autorytaryzmem i Totalitaryzmem 41, nr 4, 2019

(C) for this edition by CNS 
Strumilin S., Problemy socjalizmu i komunizmu w ZSRR, przeł. Z. Dąbrowa et al., Warszawa 1962. Studnicki F., Cybernetyka i prawo, Warszawa 1969.

Stalin J., Dzieła, t. 4, Warszawa 1951.

Suchodolski B., Wychowanie dla przyszłości, Warszawa 1959.

Wacławek J., Kształtowanie się socjalistycznych stosunków międzyludzkich w zakładzie przemystowym, Warszawa 1965.

Walicki A., Dwa spojrzenia „ex post”. Część druga - 1990, [w:] idem, Zniewolony umyst po latach, Warszawa 1993.

Walicki A., Marksizm i skok do królestwa wolności. Dzieje komunistycznej utopii, Warszawa 1996.

Wiatr J., Szkice o materializmie historycznym i socjologii, Warszawa 1962.

Wiecki W., Administracja publiczna a rozwój kultury, [w:] Socjalistyczna teoria organizacji. Koncepcje — kierunki, red. S. Kowalewski, Warszawa 1977.

Woleński J., Kotarbiński, Warszawa 1990.

Wytyczne na VII Zjazd PZPR, Warszawa 1975.

Zbichorski Z., Kształcenie i doskonalenie inżynierów organizatorów na tle doświadczeń ZSRR, [w:] Wplyw Wielkiej Socjalistycznej Rewolucji Październikowej i nauki radzieckiej na rozwój organizacji i zarządzania w PRL. 60-lecie Wielkiej Socjalistycznej Rewolucji Październikowej. Ogólnokrajowa konferencja naukowa, Warszawa 1977.

Zdyb M., Zarys historii myśli organizatorskiej, Lublin 1987.

Zieleniewski J., Nauki o organizacji i kierowaniu a praktyka działania, „Przegląd Organizacji” 1976, nr 4-5.

Zieleniewski J., Organizacja zespołów ludzkich, Warszawa 1964.

Zych J., Koncepcja funkcji kierowniczych i nie kierowniczych w instytucji socjalistycznej, [w:] Socjalistyczna teoria organizacji. Koncepcje - kierunki, red. S. Kowalewski, Warszawa 1977.

\section{BETWEEN IDEOLOGY AND PRAXIS. SOCIALIST ORGANIZATION \\ IN THE POLISH PEOPLE'S REPUBLIC (1956-1981)}

\section{Summary}

The end of World War II coincided with the beginning of the process of establishing the Polish new order whose references were the political, social and economic solutions of the USRR, while its ideological basis was Marxism interpreted by Lenin and Stalin. The establishment of the new political system in accordance with official ideology required transposing its ideas to the practical ground with practical sciences acting as a bridge between abstract thinking and reality. The subject of the following article is an analysis of the assumptions of the Polish socialist organizational studies and its connection with Marxism-Leninism in the years 1956-1981.

Keywords: socialist organization, organizational studies, Marxism-Leninism, socialism, the Polish People's Republic, ideology.

Rafał Kania

rafalkania@op.pl 